Saint Louis University School of Law

Scholarship Commons

All Faculty Scholarship

2000

Health Care Divided: Race and Healing a Nation

Sidney D. Watson

Follow this and additional works at: https://scholarship.law.slu.edu/faculty

Part of the Civil Rights and Discrimination Commons, and the Health Law and Policy Commons 


\section{HEALTH CARE DIVIDED: RACE AND HEALING A NATION}

\section{Sidney D. Watson}

To cite this article: Sidney D. Watson (2000) HEALTH CARE DIVIDED: RACE AND HEALING A NATION, Journal of Legal Medicine, 21:4, 601-608, DOI: 10.1080/019476400455825

To link to this article: https://doi.org/10.1080/019476400455825

Published online: 29 Oct 2010.

Submit your article to this journal $₫$

山 Article views: 30 


\section{Health Care Divided: Race and Healing a Nation}

David Barton Smith (University of Michigan Press, Ann Arbor, Michigan, 1999), 386 pages, $\$ 39.50$.

Reviewed by Sidney D. Watson, J.D., Macon, Georgia. *

\section{TELLING THE STORY}

Race matters. Race-particularly racial segregation-casts a pervasive shadow over the organization of American health care. It influences the ownership and governance of institutional providers. It helps account for the high cost of health care in the United States. It contributes to America's abysmal health status, among the worst of the industrialized world. It is reflected, in part, in the lack of national health insurance. So David Barton Smith begins this book, a book he describes as the story of "a divided nation, a divided health care system, and the uncompleted journey to heal both."1

Most of us are not comfortable talking about race and racism. Race is not a biological determinant and to focus on race seems to run afoul of the American melting pot theory. Talking about racism is even harder because to be racist is to use one's individual and institutional power to exclude others. To talk of race and racism is to acknowledge the capacity and willingness of members of our society, either intentionally or unconsciously, to wield this power to harm others.

To talk about race, racism, and health care is particularly awkward because we know so little about it. The government gathers statistics on racial segregation in housing, schools, and jobs, so we have information to inform these discussions. With health care, no one reports data on segregation. More federal dollars go to health care than flow to housing, schools, and jobs combined, yet we know less about the effects of race and racism on access to and quality of medical care. This book is a call to begin gathering and reporting race-based health care data.

\footnotetext{
* Professor of Law, Mercer University School of Law. Address correspondence to Professor Watson at Mercer University School of Law, 1021 Georgia Avenue, Macon, Georgia 31211, or via e-mail at <sdwatson@aol.com>.

${ }^{1}$ David Barton Smith, Health Care Divided: Race and Healing a Nation 5 (1999).
} 
David Barton Smith and others have told bits and pieces of the health care civil rights story, ${ }^{2}$ but this book provides students, scholars, and policy makers with a definitive work that pulls together history, statistics, and organizational theory in a sweeping, yet detailed, look at race and health care in the United States. Smith marshals the published data on race and health care, explaining the significance of the research to those less adept at statistical analysis. The true heart of the book, though, is personal narrative. Supported by a Robert Wood Johnson Foundation Health Policy Research Investigator Award, Smith traveled extensively, interviewing those involved in the health care civil rights struggle. The book provides lengthy quotes from these oral sources as well as written recollections, allowing the participants to tell this story.

The book is divided into two parts. Part I, infused with personal stories, presents the history of civil rights and health care. Chapter 1 describes the evolution of America's racially segregated health care system. First-person narratives paint a picture not of a benign system of separate institution s but of a white-dominated medical culture that not only refused to care for Blacks ${ }^{3}$ but also denied Black professionals entry into medical practice and medical specialties to be able to care for their own. Chapter 2 tells of the early battles to integrate hospitals at the national level, while chapter 3 focuses on the struggle in North Carolina, the site of important legal precedent. Chapter 4 recounts the initial efforts to enforce Title VI of the Civil Rights Act in the health care context during implementation of Medicare. Chapter 5 brings the story up to date describing the decline — and some would say fall—of concern about civil rights issues in medicine.

Part II, which relies more heavily on statistics, examines how this history of segregation and limited civil rights enforcement continues to affect Americans' health and their health care system. Chapter 6 presents the published research on race-based differences in health status and access to care, including the extent to which hospitals, nursing homes, and outpatient care continue to be segregated by race. The chapter concludes by describing the ways in which the health care system has reshaped itself to accommodate racial sensibilities - and prejudices - in the face of selective and limited civil rights enforcement. Chapter 7 focuses on segregation in long-term care, while chapter 8 looks at maternal and child health.

In Chapter 9, the book's conclusion, David Barton Smith applies organizational theory to the history, narrative, and statistics laid out in the previous

\footnotetext{
${ }^{2}$ See, e.g., David Barton Smith, Addressing Racial Inequities in Health Care: Civil Rights Monitoring and Report Cards, 23 J. Health Pol. Pol'y \& L. 75 (1998); Vernellia R. Randall, Trusting the Health Care System Ain't Always Easy! An African American Perspective on Bioethics, 15 St. Lous U. Pub. L. Rev. 191 (1996); Ken Wing, Title VI and Health Facilities: Forms Without Substance, 30 Hastings L.J. 137 (1978).

${ }^{3}$ I use an upper case "B" because I believe that the term "Black" denotes a specific cultural group rather than merely a skin color and therefore requires use of a proper noun.
} 
chapters. He identifies six lessons and then suggests how they might be applied to bring together-or, using David Barton Smith's word, "heal"- - a divided health care system.

\section{Lesson 1. The Role of Black Professionals}

Black physicians and dentists played a key role in the emergence of the civil rights struggle of the 1950s and 1960s. In many communities, they constituted the backbone of the movement. These Black professionals could afford to take a leadership role because they were insulated from white retaliation. Excluded from white hospitals, they controlled the institution s where they practiced. As solo, fee-for-service practitioners, they relied on their patients, rather than health insurance, for payment. Today, such independence is gone. Black professionals no longer control the hospitals where they practice. Their income is predominantly from private managed care organization s and insurers. These institution s and third-party payers can, and do, discipline "uncooperative" practitioners. Smith registers his concern that this loss of economic independence may signal the demise of Black physicians and dentists as civil rights advocates for their patients.

\section{Lesson 2. The Role of Private Hospitals}

Voluntary hospitals, because of their lack of public accountability, have both contributed to and helped to eliminate racial segregation in health care. While other countries primarily provide hospital care through public institutions, the American scene is dominated by voluntary, not-for-profit hospitals, which account for $60 \%$ of hospitals and $71 \%$ of hospital beds. ${ }^{4}$ Initially, these private hospitals created America's segregated health care. Organized by religious, ethnic, and racial groups to care for their own, voluntary hospitals operated by Protestants excluded Catholics, those operated by Catholics excluded Jews, and all those run by and for whites excluded Black physicians and patients. Black Americans responded as others before them, by establishing their own voluntary hospitals to care for themselves. The result was a rigidly racially segregated system of hospital care.

When the civil rights movement began advocating for integrated services and the Black vote became more important in northern cities, publicly owned hospitals succumbed to political pressure and opened their doors to Black physicians and their patients. Voluntary hospitals, though, were insulate d from these pressures. It required the dismantling of the legal underpinnings of "separate but equal" to desegregate America's private hospitals. Three legal milestones mark this journey.

\footnotetext{
${ }^{4}$ SмIтH, supra note 1 , at 314.
} 
First, in 1963, in Simkins v. Moses H. Cone Memorial Hospital, ${ }^{5}$ the court found the federal Hill-Burton Act's "separate but equal" provision unconstitutional and held that private hospitals that received Hill Burton money could no longer exclude Black physicians and Black patients. One year later, in 1964, Congress enacted Title VI of the Civil Rights Act $^{6}$ prohibiting institutions, including hospitals, that received federal funds from discriminating on the basis of race. Next, in 1965, Congress enacted Medicare and Medicaid. Suddenly, almost every voluntary hospital began receiving federal money, became subject to the new civil rights law, and could no longer practice racial segregation.

Amazingly, given the histrionic s of the time, most private hospitals desegregated quickly and quietly. Within a year, almost a thousand hospitals integrated. In Atlanta, Grady Hospital's twin patient towers-one Black and one white-integrated one night without a single patient complaint. In North Carolina, the Black and white hospitals in one community merged quietly and voluntarily, in less than six weeks. As private institutions, hospitals were able to avoid the local politics, public scrutiny, and divisivenes s that embroiled public schools and universities for decades.

\section{Lesson 3. The Primacy of Economic Self-Interest}

While race and racism play a role in shaping the health care delivery system, the power of money dominates. Purchasers of health care define the economic self-interest of providers and can, in that role, narrow or widen racial divisions. A theme that plays throughout the book is that health care professionals and institution s are rational economic actors. Rarely, if ever, has racial prejudice taken precedence over economic self-interest. Unfortunately, though, providers' views of their economic self-interest is often filtered through their own racial bias. Thus, nursing homes continue to limit the number of Black patients they admit for fear that white patients will shun an institution they perceive as "too Black."

Smith stresses that purchasers have the financial power to shape provider behavior and can use that power to reduce racial segregation and restructure the health care delivery system. The federal government accomplished this in 1966 when Medicare required, as a condition of participation, that hospitals admit Black patients and desegregate their wards. Hospitals needed the Medicare dollars, so they desegregated.

Purchasers set the rules and these rules can either enforce segregation or reduce it; the choice lies with the purchaser. On the other hand, attempts to enforce civil rights laws without a direct and obvious connection to the

\footnotetext{
5323 F.2d 959, 969 (4th Cir. 1963) (en banc).

642 U.S.C. $§ 2000$ d.
} 
purchase of care amounts to tilting at windmills, an empty and ultimately frustrating gesture.

\section{Lesson 4. Selective Enforcement of Title VI}

The selective enforcement of Title VI of the 1964 Civil Rights Act has profoundly shaped the organization of medical care in this country. Buffeted by political foes and staffing limitations, the federal government has had to limit its civil rights efforts. In health care, this translated into focusing exclusively on hospitals. Nursing homes and physician offices have escaped scrutiny.

For hospitals, civil rights enforcement targeted one easily documented and widespread practice, segregated ward and room assignments. ${ }^{7}$ Title VI enforcement quickly and effectively desegregated hospital beds. However, the medical system just as quickly adapted to accommodate deeply entrenched white fears. Acute care hospitals moved from wards and double rooms to primarily single rooms-with higher costs-where whites would not have to lie next to Blacks. At the same time, the number of nursing home beds doubled and the cost of long-term care skyrocketed as recuperative care moved out of hospitals and into nursing homes, where rooms continued to be segregated by race. Increasingly, services moved from hospitals, where people might have to lie next to each other, to outpatient settings, where recuperative lying down is done in the privacy of one's home. Although other factors contributed to this restructuring of American health care, racial bias and selective Title VI enforcement played a significant role.

\section{Lesson 5. Segregation Continues and Harms Black Americans}

America still has a segregated health care system. Today's health care segregation mirrors geographic and residential segregation, and is compounded by providers' economic decisions to locate in affluent, primarily white suburban areas rather than minority neighborhoods. The result is a system in which nursing homes and outpatient care are more segregated than hospitals, and segregation is more pronounced in the Northeast and Midwest than in the South. It also means that Blacks have less choice of providers, particularly when it comes to physician services, long-term care, and home health care, because these providers tend to shun minority neighborhoods .

Present-day segregation means that Blacks receive care from different types of institutional providers. Public hospitals, teaching hospitals, and

\footnotetext{
${ }^{7}$ Historically, segregation depended upon one's angle of repose. Races could mix when they were standing, but not when they sat and certainly not when they layed down. Compare, for example, old rules regarding segregated lunch counters, buses, and hotels with racial mixing in stores and other venues where one stood up.
} 
clinics are more likely to be located in minority neighborhoods and to serve minority patients than are private hospitals and physician practices. Although more and better data are needed to better understand how these new forms of segregation impact health outcomes, policy discussions about health care financing and organization cannot ignore the racial divide in where and how people obtain care.

We also need to be careful not to attribute the characteristics of medical institutions to the racial groups they serve. Teaching and public hospitals have tended to provide fragmented, episodic, acute care. Rather than accusing African Americans of being unwilling to take "personal responsibility" for their health, we need to realize that the institution s they tend to use do not encourage preventive care and long-term health education.

Moreover, at least some of the apparent racial differences in health and health status may be the result of the testing and reporting practices of institutions that serve the Black community. For example, the urban clinics and teaching and public hospitals that Blacks frequent are not only more likely to screen for drug addiction and sexually transmitted diseases but also may be more likely to record the results by race. Voluntary hospitals and private physicians are not only less likely to do such screening but are also less likely to report the results by patient race-both practices that can result in dramatic underreporting. A recent review of infant deaths in Philadelphia found a systematic racial bias in reporting. Most Black births in Philadelphia take place at a few teaching hospitals, which report the deaths of nonviable fetuses as live births and infant deaths. The suburban community hospitals where most white births take place generally do not record nonviable fetuses in their infant mortality figures. This discrepancy in recordkeeping accounts for about half the difference in Black and white infant mortality rates in Philadelphia ${ }^{8}$

\section{Lesson 6. Health Care Institutions Can Mend Racial Divides}

For Smith, the most powerful part of America's struggle with race and health care is the almost magical way hospitals voluntarily desegregatedrapidly and without fanfare. Smith sees this as powerful evidence that racism is not an inevitable part of the American medical system. American physicians and medical institution s were given great latitude to desegregate hospitals, and they used it to accomplish the quietest and smoothest transition of the civil rights struggle. The effectiveness of this delegation of authority-particularly in light of the limited role that the federal government has played in enforcing civil rights in health care-argues for a broader appeal to the sense of physicians, hospitals, and other providers that they should "do the right thing" and seek to eliminate racism in medical care.

${ }^{8}$ SMITH, supra note 1 , at 224. 


\section{APPLYING THE LESSONS}

Smith's lessons return us to the book's beginning. We do not really know enough about the nature and extent of racism in health care to deal effectively with the problem. It is impossible to eliminate racism in today's world of medical care without comprehensive, accurate racial data about the use of health services. Any racial discrimination that occurs in health care today is subtle compared to the overt discrimination of segregated facilities. It is also entangled with and driven by the "new economics" of health care. At the structural level, it is shaped by residential segregation that causes a sparsity of health care providers in minority neighborhoods as compared with affluent, predominantly white communities. At the interpersonal level, it is shaped by trust or distrust, affinity, and expectations that both providers and patients bring to the encounters. In many instances, neither the provider nor the patient is aware of how race matters. Data by race and ethnicity on access, quality, and outcomes are needed to educate us about the complex role of race in present-day health care.

Reporting race-based data on health care is relatively easy once we get over our squeamishness about talking about race and recognize the need for this information. Physicians already gather information on patient race as part of a standard medical history. All that is needed is to compile and report racial and ethnic information in a format that protects patient confidentiality and privacy. Existing and proposed health care "report cards" offer a readymade system for data collection on access, quality, and outcomes. Most have undergone extensive development and review. Only minor formatting changes are needed to expand report cards to include information about race and ethnicity.

Publicly available, institution-speci fic racial information can create the impetus for providers to voluntarily reduce racial and ethnic disparities in care. Many of the gains in health care civil rights have come as a result of providers' voluntary efforts to reduce segregation, often, but not always, in response to their economic self-interest. Race-based report cards that reflect racial disparities signal that some form of racism-intentional or unintentional, institutional or individual - is affecting patient care. It is only when provider s know that something is "wrong" that they can be motivated to change the status quo to do what is "right."

Just as importantly, publicly available race-based data can be used to create economic incentives to reduce racial disparities. Third-party payers can tie reimbursement to reductions in race-based disparities. A key goal of the Healthy People 2000 report is the elimination of racial and ethnic health disparities. Efforts are afoot to require Medicaid and Medicare managed care plans to meet similar goals. Moreover, in an increasingly racially diversified America, the reduction and elimination of racial disparities can be an effective patient recruitment strategy. 


\section{CONCLUSION}

Researchers sometimes do not know, forget, or are unimpressed that Dante reserved the seventh level of hell for those who recognize a problem and do not attempt to do anything to solve it. ${ }^{9}$

David Barton Smith avoids the inferno. His book both names the problem - race discrimination in health care combined with limited civil rights enforcement - and identifies a solution. His solution, race-based data reporting, will allow us to begin talking about race, racism, and health care. It also creates the impetus for well-meaning and economically self-interested health care professionals and institution s to reduce racism once they-and we-better understand its nature.

${ }^{9}$ Id. at 312 (citing David Falcone \& Robert Broyles, Access to Long Term Care: Race as Barrier, $19 \mathrm{~J}$. Health Pol. Pol'y \& L. 593 (1994)). 